\title{
Variations of chemical composition and energy content in natural and genetically defined cultivars of Macrocystis from Chile
}

\author{
Renato Westermeier • Pedro Murúa • David J. Patiño • \\ Liliana Muñoz • Ailin Ruiz • Dieter G. Müller
}

\begin{abstract}
Seasonal and intra-thallus variations of energy content and chemical composition were assessed in an intertidal population of Macrocystis in southern Chile. Phylloid protein and lipid from cultured material were compared with seasonal variation in native Macrocystis. Furthermore, populations in northern and southern Chile and Falkland Islands were compared with various intra-/ inter-cultivar genotypes of Chilean Macrocystis. Energetic values did not show seasonal or intra-thallus variations, with the exception of pneumatocysts, which had high levels of ash $(49.9 \% \mathrm{DW})$ and low values of total energy $(8.3 \%$ DW). Seasonal patterns were detected in protein and carbohydrate composition, with opposite trends. Likewise, holdfasts contained high amounts of protein $(21.0 \% \mathrm{DW})$, and phylloids were high in soluble carbohydrates $(4.5 \%$ DW). Lipids instead showed two peaks per year in an intertidal population and reached up to $0.4 \% \mathrm{DW}$. Alginic acid was the major organic compound in intertidal Macrocystis (46.8\% DW), with differences on seasonal and intra-thallus levels. Mannitol content, in contrast, was erratic and lower than in other Laminariales $(<5 \% \mathrm{DW})$. In general, protein and lipid content in our
\end{abstract}

R. Westermeier $(\bowtie) \cdot$ P. Murúa $\cdot$ D. J. Patiño $\cdot$ L. Muñoz $\cdot$ A. Ruiz Instituto de Acuicultura, Universidad Austral de Chile, Sede Puerto Montt, Casilla 1327,

Puerto Montt, Chile

e mail: rwesterm@uach.cl

D. G. Müller

Fachbereich Biologie, Universität Konstanz,

78457 Konstanz, Germany cultivars were $20 \%$ higher than in natural populations. Our experimental results indicate the possibility to manipulate the chemical composition of Macrocystis thalli through inter-/intra-specific crosses. This will be a basis, upon which selected genotypes can open new perspectives to Macrocystis mariculture industries in Chile.

Keywords Macrocystis · Phaeophyta $\cdot$ Cultivar · Natural population $\cdot$ Chemical composition $\cdot$ Seasonality

\section{Introduction}

In recent years, algal resources have reached many applications, as source of chemical constituents for various industries, including valuable compounds for animal and human nutrition (Mc Hugh 2003). Brown algae are mainly used in alginic acid industry, as herbivore food for marine and terrestrial animals, human food, and recently biofuels, natural fertilizers, and biofilter applications (Kraan 2010).

The giant kelp Macrocystis represents the most intensely studied seaweed resource in the world, with major focus devoted to ecological and economic importance of kelp forests. Particularly in Chile, Macrocystis offers food and habitat to endemic marine invertebrates. In addition, it has been exploited for more than five decades to support alginate and abalone industries, being used as dried raw material (pellet or flour) and fresh food.

Currently, the increasing demands for these kelp products, in addition to poor management and repopulation efforts, have 
caused severe overexploitation of Macrocystis populations. Chilean government statistics reported that $98 \%$ of the 17,000 t landed during 2008 refer to "northern huiro" (i.e., Macrocystis integrifolia), reflecting a significant increase of extractions in more $500 \mathrm{~km}$ of coast, in addition to natural populations of Macrocystis pyrifera in south Chile (Sernapesca 2009).

This scenario is closely connected with haliotid culture. In Chile, abalone mariculture began in 1989 with the introduction of Californian and Japanese abalone species (Haliotis rufescens and Haliotis discus hannai). In 2008, this industry generated an income of US \$14 million with 900 t landed (source: ProChile 2011). This production level required 90-100 t of fresh brown algal biomass month ${ }^{1}$ per culture center. Considering that only phylloids (representing $40 \%$ of total algal biomass) are used for food, together with an expected rise in abalone production, the industry is likely to demand $100,000 \mathrm{ty}^{1}$ of brown seaweed in the near future (Macchiavello et al. 2010).

The use of Macrocystis as food source for abalone depends on two main factors: (1) availability of biomass, where kelp forests represent in most locations the dominant seaweed in terms of biomass (Graham et al. 2007), and (2) the nutritional value, supporting the fast and healthy growth of the abalone animals (Hahn 1989). The ecological and economic implications of kelp extinction in the vicinity of abalone cultivation farms generated a strong interest to consider Macrocystis mariculture as a possibility to meet the growing demand of biomass (Westermeier et al. 2006, 2011).

However, in addition to production of biomass, there remains an additional crucial factor for abalone cultivation: Up to the present, there is a significant deficit in knowledge of the chemical composition of natural or cultivated Macrocystis and its nutritional value for abalone production. Therefore, the aim of this study is to report and compare for the first time variations in chemical composition between Macrocystis from natural beds and cultivation.

\section{Materials and methods}

Although several authors recognized Macrocystis pyr ifera and M. integrifolia as the same species (Coyer et al. 2001; Westermeier et al. 2007; Macaya and Zucarello 2010), we choose here to maintain the traditional nomenclature to avoid confusion and to keep consistency with our previous reports. Triplicate samples of entire $M$. pyrifera and $M$. integrifolia thalli from natural beds were harvested from III, XIV, and X regions (Table 1). $M$. pyrifera from Mehuín (MEH) was collected monthly in the years 1988 and 1989 and used to study seasonal and intra-thallus changes of chemical and energetic composition. Single collections from MEH, Maullín (MAU), Falkland Islands (FI), and Bahia Salada (BSA; Table 1) were used to determine site-specific differences in protein and lipid content of phylloids.

Intertidal samples were collected directly from rocky shore during low tide and subtidal samples through SCUBA diving. After harvest, samples were transported in sterile polyethylene bags at $5^{\circ} \mathrm{C}$ to the laboratory, rinsed and cleaned from visible epiphytes (i.e., ectocarpalean algae) and epifauna (especially bryozoans), and separated into holdfast, stipes, pneumatocysts, and phylloids. Samples were dried at $60^{\circ} \mathrm{C}$ for 3 days and powdered as described by Westermeier (1982) and stored at ambient temperature until further analysis. Moisture in all samples was less than $3 \%$.

\section{Collections from cultured Macrocystis}

Laboratory and mariculture experiments were carried out in two periods: (1) in 2002-2003 to determine seasonal changes

Table 1 Collection sites, dates, and code designations for native Macrocystis from northern (M. integrifolia) and southern Chile (M. pyrifera)

\begin{tabular}{|c|c|c|c|c|}
\hline \multicolumn{5}{|c|}{ Natural population } \\
\hline Specie & Code & Habitat & Locality & Collection date \\
\hline M. pyrifera & & Intertidal (Pacific Open Sea) & Mehuín (39²4' S) & September 1988 August 1989 \\
\hline M. pyrifera & $\mathrm{MEH}$ & Intertidal (Pacific Open Sea) & Mehuín (39²4' S) & September 1988 \\
\hline M. pyrifera & FI & Subtidal (Atlantic Open Sea) & Falkland Island $\left(51^{\circ} 30^{\prime} \mathrm{S}\right)$ & February 2008 \\
\hline M. pyrifera & MAU & Subtidal (Pacific Open Sea) & Maullín (41³7’ S) & September 2010 \\
\hline M. integrifolia & BSA & Subtidal (Pacific Open Sea) & 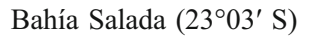 & September 2007 \\
\hline
\end{tabular}


Table 2 Collection origin and cultivar designations for Macrocystis gametophyte clones

\begin{tabular}{llll}
\hline Locality/cultivar & Habitat & \multicolumn{2}{l}{ Gametophyte clones } \\
\cline { 3 - 4 } & & Female & Male \\
\hline p1 & Semiprotected (S) & p1f & p1m \\
p3 & Interior Sea (S) & p3f & \\
p5 & Open Pacific (S) & & p5m \\
p6 & Open Pacific (S) & p6f & p6m \\
p7 & Interior Sea (S) & p7f & \\
i8 & Caldera 27 03' S & & i8m \\
i9 & Open Pacific (N) & i9f & i9m \\
i10 & Open pacific (N) & & i10m \\
\hline
\end{tabular}

Data were updated from Westermeier et al. (2011)

$p$ M. pyrifera, $i$ M. integrifolia, $f$ female, $m$ male gametophyte parent

of lipid and protein levels in phylloids of cultured Macrocystis (p6f $\times$ p6m cultivar; see Table 3) and (2) in 2008-2009 to detect differences in chemical composition between phylloids of various artificially constructed cultivars (Westermeier et al. 2006, 2007, 2010, 2011; Tables 2 and 3). Establishment and maintenance of cultivars and seedling production followed the techniques described by Westermeier et al. (2006, 2007).

Mariculture installations were established at depths between 4 and $6 \mathrm{~m}$, with a density of 6 thalli per linear meter $\left(\mathrm{m}^{1}\right)$, near (1) Calbuco, Llanquihue, $\left(41^{\circ} 45^{\prime} \mathrm{S}\right)$, a semiprotected bay in southern Chile, and (2) a sheltered shore in Chiloé $\left(42^{\circ} 28^{\prime} \mathrm{S}\right.$; Table 3). Samples were harvested in triplicate when thalli had reached $\geq 50 \mathrm{~cm}$ in size, with monthly frequency in the period 2002-2003 and one time in cultures 2008-2009 (see Table 3). After collection, cleaning, drying, and storage, the materials were treated as described above.
Physicochemical factors in seawater (nutrients and temperature) were determined in each locality where samples were collected (natural populations and mariculture installations), at $5 \mathrm{~m}$ depth. In Calbuco was regarded throughout 1 year whereas in Bahia Salada, Chiloé Island and Maullín were recorded during unique sample, coincident with seaweed harvest period. In Mehuín, physicochemical factors were not sampled, and there are not reports by other authors. However, to complement environmental information, we add information collected during 2000-2001 in Faro Corona $\left(41^{\circ} 45^{\prime} \mathrm{S} ; 74^{\circ} 00^{\prime} \mathrm{S}\right)$, southern Chile, an exposed coast in Chiloé Island, $250 \mathrm{~km}$ south Mehuín with similar physical conditions and where M. pyrifera occurs also. In Falkland Island, nutrient and temperature values were not determined in sample period, but February temperature recorded by van Tussenbroek (1989) was used.

\section{Chemical analysis}

Protein levels were estimated from total nitrogen content using the routine Kjeldahl method, converting total nitrogen with the factor 6.25 (Steubing 1965; Westermeier 1982; AOAC 1990). Lipid contents were determined by the gravimetric method of Roughan (1985). Soluble carbohydrates were quantified by colorimetry (phenol sulfuric method) according to Dubois et al. (1956), and mannitol and alginic acid were measured after Cameron et al. (1984), this last one by isolation and displacement of acetic acid from calcium acetate.

Energetic content (KJ g $\left.{ }^{1} \mathrm{DW}\right)$ and ash content were measured by igniting $1 \mathrm{~g}$ dry weight of algal material in a Parr adiabatic bomb calorimeter. Subsequently, ash content was determined by burning $1 \mathrm{~g}$ of algal dry matter for $4 \mathrm{~h}$ in a muffle furnace at $450^{\circ} \mathrm{C}$ (Westermeier 1982). Except for energetic content, all values were expressed as percentage of algal dry weight $(\% \mathrm{DW})$.
Table 3 Collection sites, dates, and code designations of cultivars

\begin{tabular}{llll}
\hline Culture & & & \\
\hline Species & Code & Cultivation locality & Collection date \\
\hline M. pyrifera & $\mathrm{p} 1 \mathrm{f} \times \mathrm{p} 1 \mathrm{~m}$ & Chiloé Island $\left(42^{\circ} 28^{\prime}\right)$ & September 2008 \\
M. pyrifera & $\mathrm{p} 6 \mathrm{f} \times \mathrm{p} 6 \mathrm{~m}$ & Llanquihue, Calbuco $\left(41^{\circ} 45^{\prime}\right)$ & September 2002 \\
M. pyrifera & $\mathrm{p} 7 \mathrm{f} \times \mathrm{p} 5 \mathrm{~m}$ & Chiloé Island $\left(42^{\circ} 28^{\prime}\right)$ & September 2008 \\
M. integrifolia & $\mathrm{i} 9 \mathrm{f} \times \mathrm{i} 9 \mathrm{~m}$ & Chiloé Island $\left(42^{\circ} 28^{\prime}\right)$ & September 2008 \\
M. integrifolia & $\mathrm{i} 9 \mathrm{f} \times \mathrm{i} 10 \mathrm{~m}$ & Chiloé Island $\left(42^{\circ} 28^{\prime}\right)$ & September 2008 \\
Hybrid pyr integ & $\mathrm{p} 3 \mathrm{f} \times \mathrm{i} 8 \mathrm{~m}$ & Chiloé Island $\left(42^{\circ} 28^{\prime}\right)$ & September 2008 \\
\hline
\end{tabular}


Statistical analysis

Differences in chemical composition between $M$. pyrifera thallus sections and monthly variations were compared using the Kruskal-Wallis test. Statistical comparisons between chemical composition of cultivars and natural populations were carried out using one-way ANOVA (factor: origin; natural kelp bed or cultivar), after examining the homogeneity of variance by the Bartlett test. All tests were carried out at $95 \%$ level of confidence. Percentage values were converted by angular (arcsin) transformation (Zar 1999), to adjust data to a normal distribution.

\section{Results}

Physicochemical factors of collection localities: temperature and nutrients

Monthly variations in physicochemical factors for Faro Corona and Calbuco localities are described in Table 4. Seawater temperature in both localities fluctuated mildly, with high values in summer and low values in winter. Nutrients, instead, had erratic behavior in most cases, independent of locality. Faro Corona temperature ranged $11.3-15.4^{\circ} \mathrm{C}$, and Calbuco temperature oscillated between 9.7 and $15.3^{\circ} \mathrm{C}$. Nitrate $\left(\mathrm{NO}_{3}{ }^{2-}\right)$ was highly variable in Faro Corona, having three peaks upper $9 \mu \mathrm{M}$ (November, April, and August) but low values in rest of the year $(<5.5 \mu \mathrm{M})$, whereas in Calbuco, nitrate variations were seasonal, achieving $9.8-18.1 \mu \mathrm{M}$ in autumn-winter seasons and 0.1-6.4 $\mu \mathrm{M}$ during springsummer period.

Ammonium levels $\left(\mathrm{NH}_{4}{ }^{+}\right)$were similar for both localities. In Faro Corona, ammonium fluctuated occasionally between 0.1 and $0.7 \mu \mathrm{M}$ (reaching exceptionally high values $\geq 1.3 \mu \mathrm{M}$ in some months). In Calbuco, ammonium varied between 0.1 and $1.1 \mu \mathrm{M}$, although with high values in December $(2.6 \mu \mathrm{M})$ and April $(8.0 \mu \mathrm{M})$. Phosphate values (measured as orthophosphate $\mathrm{PO}_{4}{ }^{3}$ ) had low variation, ranging $0.5-3.0 \mu \mathrm{M}$ in Faro Corona and 0.2 $2.3 \mu \mathrm{M}$ in Calbuco. No seasonal trends were detected in both localities.

In general, punctual physicochemical factors in Bahía Salada, Chiloé Island, and Maullín did not reflect important differences among localities in temperature and nutrients (Table 5). Temperature values ranged between 11.5 and $13.5^{\circ} \mathrm{C}$, but in Falkland Island were slightly lower, even in summer $\left(\approx 9^{\circ} \mathrm{C}\right)$ : nitrate 1.1-2.4 $\mu \mathrm{M}$, ammonium $0.1-0.6 \mu \mathrm{M}$, and phosphate $0.3-0.9 \mu \mathrm{M}$. Falkland Island environmental information was not regarded.

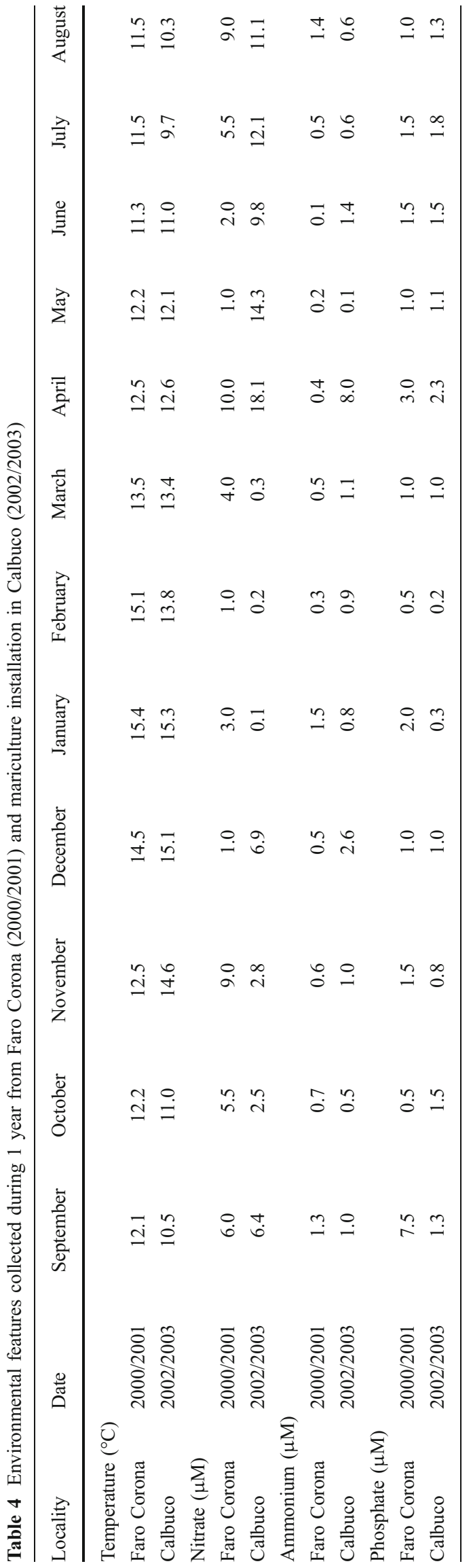


Table 5 Environmental features collected from Bahia Salada (2007), Chiloe Island (2008), Falkland Island (2008), and Maullín (2010)

\begin{tabular}{llcccc}
\hline Locality & Date & Temperature $\left({ }^{\circ} \mathrm{C}\right)$ & Nitrate $(\mu \mathrm{M})$ & Ammonium $(\mu \mathrm{M})$ & Phosphate $(\mu \mathrm{M})$ \\
\hline Bahía Salada & September 2007 & 13.5 & 2.4 & 0.6 & 0.5 \\
Chiloe Island & September 2008 & 11.5 & 2.5 & 0.2 & 0.9 \\
Falkland Islands & February 1986 & $\approx 9.0$ & nd & 1.1 & nd \\
Maullín & September 2010 & 12.5 & 0.1 & nd \\
\hline
\end{tabular}

nd not determined

${ }^{\mathrm{a}}$ Extracted from van Tussenbroek (1989)

Seasonal and intra-thallus changes in energy content, ash, and organic composition in natural populations of $M$. pyrifera

Seasonal and intra-thallus changes in energy content are shown in Fig. 1a. In general, phylloids and holdfasts presented higher energetic values than stipes and pneumatocysts. Only pneumatocysts were significantly lower $(p<0.05)$. Maximum values in total energy in holdfast were found in December, June, and August, ranging from 13.35 to $14.58 \mathrm{KJ} \mathrm{g}^{1} \mathrm{DW}$. Phylloids reached $13.20 \mathrm{KJ} g{ }^{1} \mathrm{DW}$ for total energy on March but dropped 2 months later in May to 12.70 KJ g ${ }^{1}$ DW. Pneumatocyst energy contents were the lowest and varied antagonistically compared to holdfasts and phylloids, increasing from $8.1 \mathrm{KJ} \mathrm{g}^{1}$ $\mathrm{DW}$ in October to $11.95 \mathrm{KJ} \mathrm{g}^{1} \mathrm{DW}$ in May. Stipe energetic values remained constant, ranging between 10.00 and $12.23 \mathrm{KJ} \mathrm{g}^{1} \mathrm{DW}$.

Ash content in $M$. pyrifera from Mehuín did not show a significant seasonal variation. However, significant values of ash content sections were detected in some thallus sections (Fig. 1b; Table 6). Pneumatocysts showed the highest ash values throughout the study period, ranging between $36.2 \%$ and $49.9 \%$ DW, while ash content in holdfasts were the lowest, reaching $39.5 \%$ DW. Both reached their maximum in winter. Stipe and phylloid ash values were similar between September and April (Fig 1b).

In terms of intra-thallus allocation of major organic compounds, protein values were significantly higher in holdfasts than in phylloids. Both these thallus sections showed significant seasonal changes (Table 6), with maximum values of $21 \% \mathrm{DW}$ in holdfast and $17.8 \% \mathrm{DW}$ in phylloids between March and June (i.e., autumn). Pneumatocysts showed a similar tendency. Stipes showed a slight seasonality in protein content, being low during spring-autumn, followed by a mild increase during JanuaryFebruary (Fig. 1c).
Lipid contents fluctuated strongly, showing peaks in two seasons: spring and autumn (Fig. 1d). The pattern was similar in all thallus sections (Table 6), with higher values in holdfast compared to stipe and phylloids in September through November. Later, this effect disappeared.

Soluble carbohydrate values in different parts of the thallus showed a significant variation within the year and between thallus sections (Fig. 1e; Table 6). Phylloid contents increased sharply to $4.53 \% \mathrm{DW}$ on December, decreasing to $1.72 \%$ DW 1 month later and remained constant in subsequent months at an average of $2.3 \%$ DW. In contrast, holdfasts contained low carbohydrate values $(<1.5 \% \mathrm{DW}$ in 11 months, averaging $1.01 \% \mathrm{DW}$ during the year) but showed a unique peak in early autumn. Stipes exhibited an opposite trend compared to holdfasts, and values ranged from 1.65 to $2.76 \%$ DW between September and February, decreasing strongly in March to $0.43 \%$ DW.

Alginic acid contents fluctuated both seasonally and on intra-thallus level (Table 6), with high values in autumn and low values in early summer (Fig. 1f). Minimal values were found in holdfasts, ranging from 3.7 to $22.14 \%$ with maximal values in June and minimal in February $(p<0.05)$. Alginic acid in phylloids and stipes showed similar values, varying strongly with season and reaching more than $40 \%$ DW in autumn.

Mannitol levels are presented in Fig. 1g. They showed neither seasonality nor clear differences between thallus sections (Table 6).

Seasonal changes of organic compounds in cultured $M$. pyrifera

Variation of protein and lipid content of $M$. pyrifera phylloids in the cultivar cross $\mathrm{p} 6 \mathrm{f} \times \mathrm{p} 6 \mathrm{~m}$ (Westermeier et al. 2010) is shown in Fig. 2 and contrasted with values from a natural population in Mehuín. Protein levels in cultured Macrocystis ranged between 12\% DW (JanuaryFebruary) and 15\% DW (March-June). Values decreased 

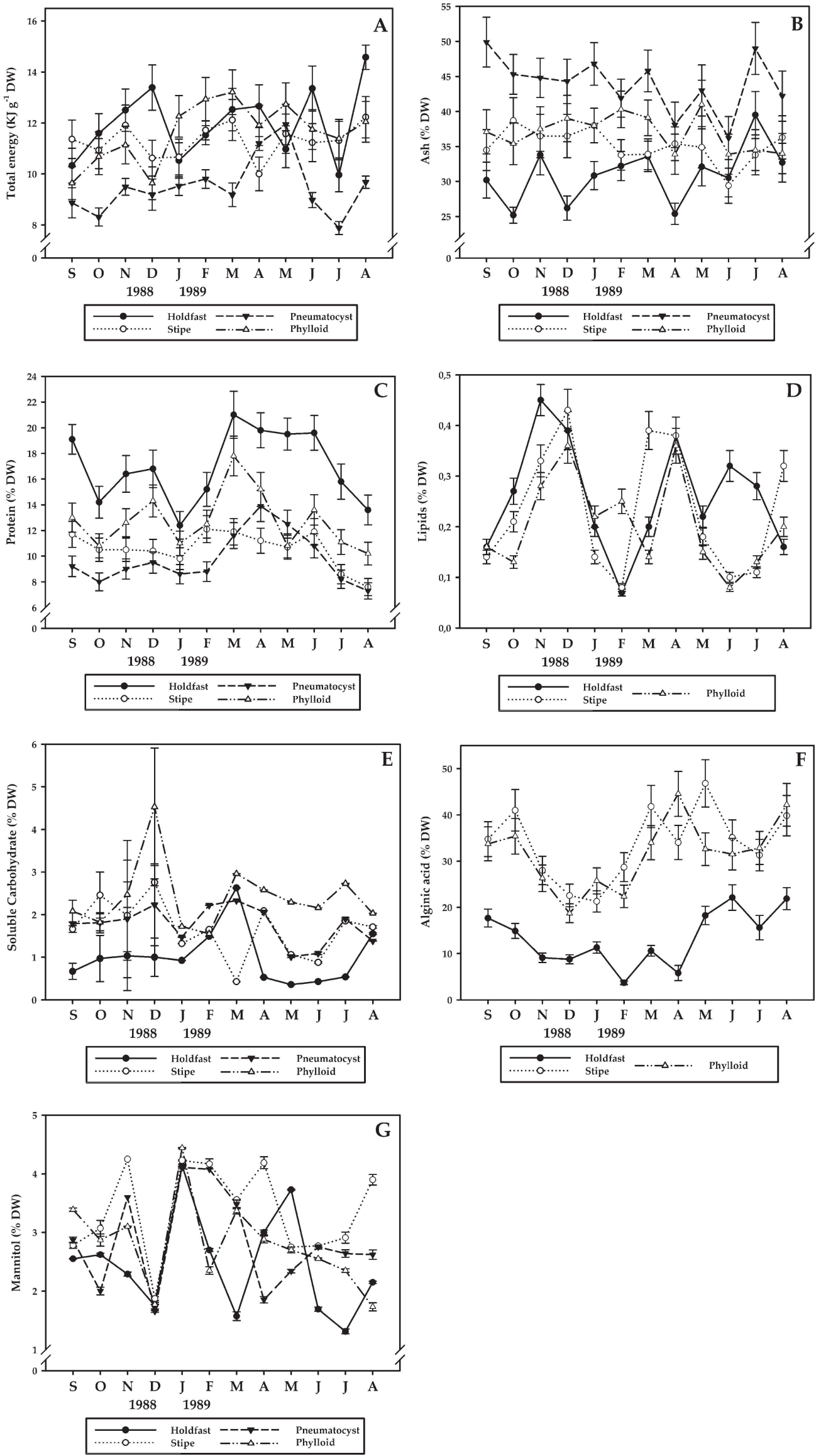
Fig. 1 Intertidal $M$. pyrifera. Temporal changes in a total energy content, $\mathbf{b}$ ash content and $\mathbf{c} \mathbf{g}$ chemical composition in four anatomic sections of thalli (holdfast, pneumatocyst, stipe, and phylloid). Data are mean $\pm \mathrm{SD}$ of four thalli

in summer, increasing mildly during early autumn and winter. The annual fluctuation was weaker than in intertidal Macrocystis, and generally phylloids from the natural population showed lower values than cultured Macrocystis. Average lipid content in cultured Macrocystis was higher than in material from natural populations. It ranged between $0.2 \%$ DW in August-September and $0.7 \%$ DW in October $(p<0.05)$

Protein and lipid composition of cultured and native Macrocystis

Protein contents in cultured (cultivars) and native Macro cystis did not show clear differences between both groups (Fig. 3a). Hybrid cross $\mathrm{p} 3 \mathrm{f} \times \mathrm{i} 8 \mathrm{~m}$ exhibited the highest protein level, reaching $15.86 \% \mathrm{DW}(p<0.05)$. In contrast, cross i9f $\times$ $19 \mathrm{~m}$ showed the lowest protein values of all phylloids analyzed (10.72\% DW). Macrocystis from natural populations instead showed high variability in their chemical composition, although their protein values were close to cultured Macrocystis and ranged between $12.57 \%$ DW (MAU) and 15.23\% DW (BSA). Lipid levels fluctuated between 0.1 and $0.4 \% \mathrm{DW}$, independent of origin (Fig. 3b). Natural material from FI and the cross $i 9 f \times$ $\mathrm{i} 10 \mathrm{~m}$ reached values of 0.89 and $0.64 \% \mathrm{DW}$, respectively, which are exceptionally high for Macrocystis. Generally, our specific crosses of defined parent genotypes showed roughly $20 \%$ higher protein and lipid contents and more homogeneity compared with Macrocystis phylloids from natural populations

Table 6 Intertidal natural $M$. pyrifera

\begin{tabular}{lrrrrr}
\hline & \multicolumn{2}{c}{ Monthly variation } & & \multicolumn{2}{c}{ Intra thallus changes } \\
\cline { 2 - 3 } \cline { 5 - 6 } & $H$ value & $p$ & & $H$ value & $p$ \\
\hline Total energy & 4.53 & $* * *$ & & 52.62 & $*$ \\
Ash & 13.64 & $* * *$ & & 80.51 & $*$ \\
Protein & 33.88 & $*$ & & 83.13 & $*$ \\
Lipid & 60.67 & $*$ & & 4.32 & $* * *$ \\
Soluble carbohydrate & 25.69 & $*$ & & 52.59 & $*$ \\
Alginic acid & 25.11 & $*$ & & 65.9 & $*$ \\
Mannitol & 4.22 & $* * *$ & & 4.90 & $* * *$
\end{tabular}

Statistical results of seasonality and thallus section on chemical composition

${ }^{*} p<0.001 ; * * p<0.05 ; * * * p>0.05$
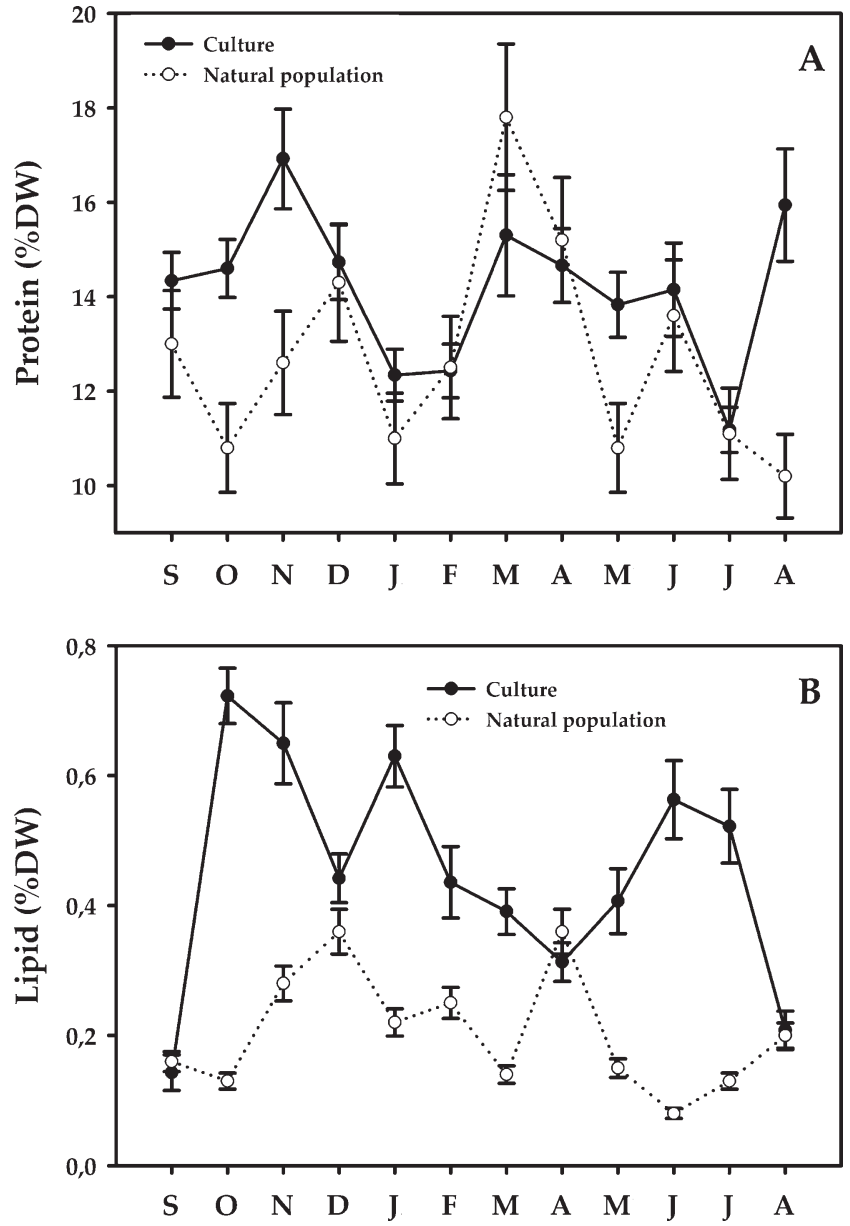

Fig. 2 Native and cultured $M$. pyrifera. Temporal changes in a protein and $\mathbf{b}$ lipid composition in phylloids. Data are mean $\pm \mathrm{SD}$ of four thalli

\section{Discussion}

Energy content in seaweeds ranges between 9.2 and $15.96 \mathrm{~kJ} \mathrm{~g}{ }^{1} \mathrm{DW}$. In members of the Laminariales, differences in calorific values are difficult to detect within genera, between seasons or various thallus sections (Paine and Vadas 1969; Lawrence and McClintock 1988). Intertidal $M$. pyrifera from Mehuín (Fig. 1a) showed values similar to those reported for Eisenia arborea in northern hemisphere (Hernández-Carmona et al. 2009) and Macrocystis, Lessonia, and Durvillaea species from southern hemisphere habitats (10-13 KJ g ${ }^{1}$ DW) and likewise did not exhibit clear differences between seasons (Westermeier 1982, 1987; Gómez and Westermeier 1995; Westermeier and Gómez 1996). However, differences occur between parts of the thalli: Minimum energy content was regarded in pneumatocysts (9.5 KJ g ${ }^{1} \mathrm{DW}$ on annual average), in contrast to 11.6 KJ g ${ }^{1} \mathrm{DW}$ on annual average for the rest of the thalli. This coincided with ash content, which was the highest in 

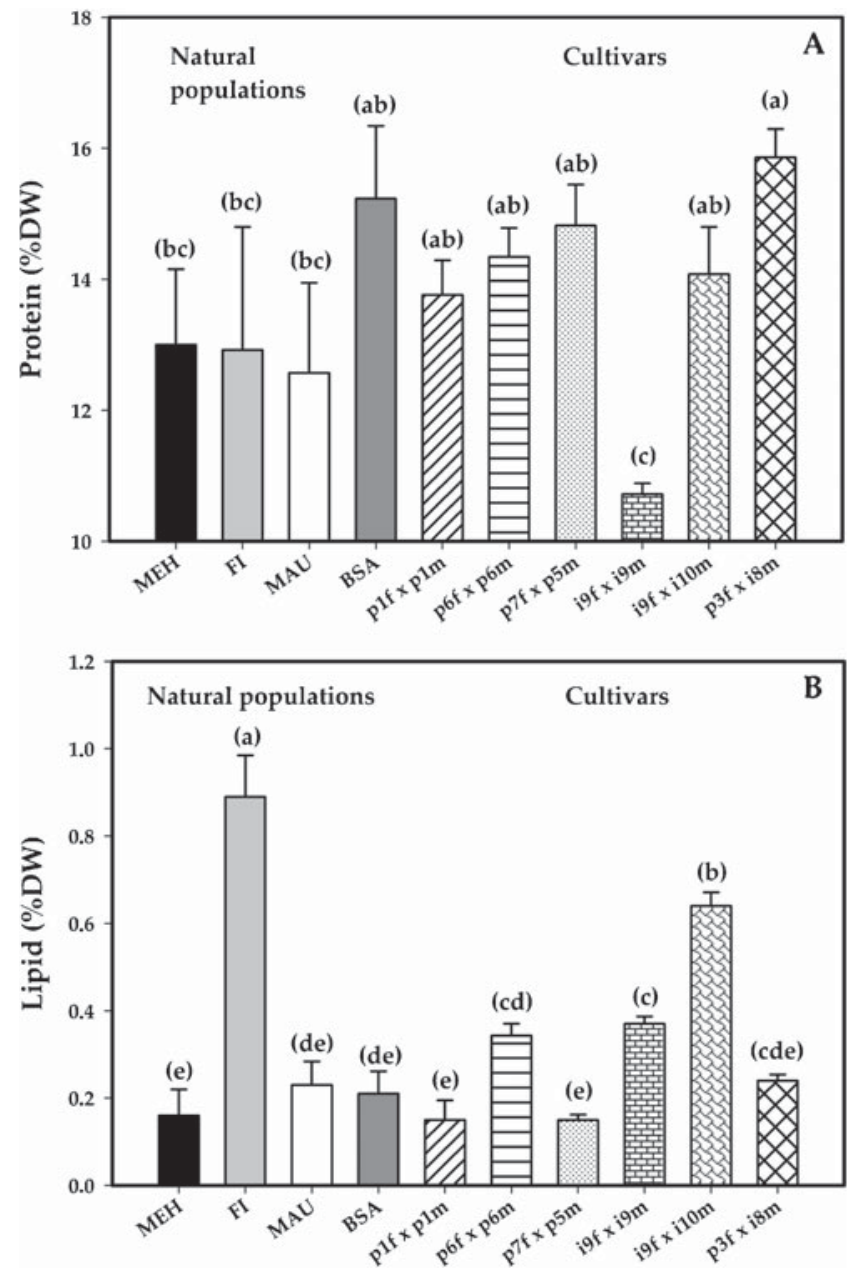

Fig. 3 Native and cultured Macrocystis. Phylloid content of a protein and $\mathbf{b}$ lipid in natural populations and various experimental sporo phyte genotypes. Data are mean \pm SD of four thalli. Significant different groups are denoted by upper letters, where chemical composition of $(e)<(d)<(c)<(b)<(a)$

pneumatocysts (44\% DW) and lower in phylloids $(36 \%$ DW), holdfasts (31\% DW), and stipes (35\% DW).

After correction for ash-free energy, the calorific values for pneumatocysts are on the same level as the rest of the Macrocystis thalli (Westermeier, unpublished), confirming the low variability of energetic values in the different sections of Macrocystis thalli. Furthermore, high ash content indicates presence of minerals and suggests a special tissue construction for floatability or anti-herbivory functions in pneumatocysts.

Unlike energetic values, major organic compounds showed seasonal trends. During spring and summer months, protein composition of $M$. pyrifera (indirectly determined by Kjeldahl method) decreased, while carbohydrates increased. In this part of the year, Macrocystis from southern Chile exhibits the highest growth rates (Westermeier and Möller 1990), phenomenon which may explain the observed patterns in those variables. Similar antagonistic patterns have been reported in Lessonia nigres cens and Durvillaea antarctica and also in some red and green seaweeds also (Westermeier 1982, 1987; Westermeier and Gómez 1996; Robledo and Freile-Pelegrin 2005). Tissue proteins are positively correlated with environmental supply and/or internal reserves of nitrogen, which are depleted or diluted during growth (Gorham and Lewey 1984). Carbohydrates, instead, are correlated with photosynthetic activity, and surplus carbon fixed in summer is translocated as reserve for growth under light-restricted periods (Chapman and Craigie 1978). This may also apply to mannitol (Meeuse 1962; Zimmerman and Kremer 1986), although physicochemical factors could affect this common pattern (as nutrients availability or light source). Mannitol is the major low molecular weight organic sugar in Phaeophyceae and plays an important role in osmoregulation and energetic physiology (Reed et al. 1985). In our study, mannitol contents of intertidal $M$. pyrifera varied strongly with season but did not exceed 4.5\% DW, unlike several subtidal kelps from similar latitudes such as $M$. pyrifera $(12.8 \% \mathrm{DW}), L$. nigrescens $(8.0 \% \mathrm{DW})$, or D. antarctica $(9.1 \% \mathrm{DW}$; Gómez and Westermeier 1995). As inhabitants of a typical intertidal habitat (30 linear $\mathrm{m}$ on average between tide marks), the Mehuín population is probably exposed to highly varying abiotic factors (i.e., light, temperature, salinity, desiccation) that could explain low contents and erratic variations of mannitol. Further, our results evidenced a high variability between different parts of the thalli, suggesting mannitol mobility between tissues, which has been frequently reported in other Laminariales (Lawrence and McClintock 1988; Westermeier and Gómez 1996).

Differences in lipid composition of kelps are found on interspecific, intra-thallus, or seasonal basis (HernándezCarmona et al. 2009; Nelson et al. 2002; Castro-González et al. 1994). High amounts dominate in cold habitats and/or seasons (Gómez and Westermeier 1995), although, due to complex interactions of internal processes (growth; reproduction) and external factors (environmental variables like temperature), may be difficult to interpret (Smith and Harwood 1984; Westermeier and Gómez 1996). In contrast to the findings of Lawrence and McClintock (1988) and Westermeier and Gómez (1996), who reported high values in phylloids, we did not detect differences in lipid composition between sections of thalli.

Alginic acid is the major polysaccharide of brown algae (Percival 1979). Differential allocation (higher content in stipe and phylloid compared to holdfast) is reported for many brown algae (Jensen et al. 1985). High contents of alginate give flexibility and mechanical resistance to cells and tissues, although the mannuronic acid/guluronic acid $(M / G)$ ratio (main components of alginic acid molecule) also contributes to these structural functions (Stockton et al. 1980; Zimmermann et al. 2005). Several studies have 
reported seasonal variation of alginate in Phaeophyta (Black 1948; Rosell and Srivastava 1984; McKee et al. 2002), with high values during growth periods. However, in our studies, Mehuín Macrocystis did not follow this pattern, which is in accordance with reports by other authors which also indicated poor correlation with seasonality (Wort 1955; Jensen et al. 1985)

Macrocystis populations from Mehuín are annuals, with young thalli dominating in spring-summer and becoming senescent in winter (Westermeier and Möller 1990). Seasonality effects on chemical composition in algae detected in our studies could be correlated to the age of individuals rather than to abiotic factors. Significant agedependent differences have been reported for total nitrogen, protein, lipid, ash, and several carbohydrates as mannitol, laminaran, or alginic acid in various seaweeds (Jones 1956). High levels of total nitrogen and N-protein have been reported in juvenile individuals (Westermeier 1982), reflecting high mitotic rates. Also, in the laminarian Costaria costata, it has been shown that lipid and fatty acid content increased gradually with age (Gerasimenko et al. 2010). It seems therefore that lipids are used for growth by juvenile stages and as storage products by adult thalli. In blades and stipes of young $M$. pyrifera from New Zealand, McKee et al. (2002) detected higher values of alginic acid and mannuronic acid residues than in older thalli. This was interpreted as the result of storage polysaccharide increase in blades as well an increase in blade thickness with age.

Protein and lipid contents in brown algae are generally small. Compared with natural Macrocystis, however, our cultivars were $20 \%$ richer in both types of compounds. Our hybrid constructs $\mathrm{p} 3 \mathrm{f} \times \mathrm{i} 8 \mathrm{~m}$ and $\mathrm{i} 9 \mathrm{f} \times \mathrm{i} 10 \mathrm{~m}$ were rich in protein $(16 \% \mathrm{DW})$. On the other hand, field populations from FI and BSA populations are expected to contain genotypes of high nutritional value (BSA with 15\% DW protein and FI with $0.85 \%$ DW lipid). Our breeding experiments showed that it is possible to select Macrocystis genotypes with valuable chemical composition, jointly with reduction of variability in biomass (sensu Westermeier et al. 2011) and chemical composition (Fig. 3), by the production of large batches of genetically homogeneous seedlings.

Although some seasonal trends were detected in physicochemical factors in Faro Corona and Calbuco localities, they did not reflect an important effect on chemical composition tendencies in our study. Temperature values, highly seasonal, seem did not affect composition of algal lipid, with exception of Falkland Island that had low temperatures even in summer (Table 5; van Tussenbroek 1989) and consequently high lipid values. Likewise, nitrogen sources (nitrate and ammonium) varied erratically throughout a year and did not affect significantly protein pattern of variability, and phosphate values were relatively constant in all sample period. Furthermore, values of temperature, nitrate, ammonium, and phosphate were similar to other localities in September (Bahia Salado, Chiloé Island; Maullín). Therefore, it is impossible to assume a distinctive and unique effect of environmental variables on Macrocystis chemical composition, so a second factor is relevant: genetic traits. This assumption, however, was not applicable to Falkland Island Macrocystis in this study, where environmental data were not collected. Further studies in relationship between cultivars chemical composition and physicochemical features will be carried out to discern particular effects of genetic and environment in cultured Macrocystis.

Future research in chemical composition of cultivars must be focused to two aspects: (1) The selection for higher amounts of high-value compounds like selected carbohydrates (for fuel bioconversion) or alginic acid (for alginate extraction) and (2) the characterization of low-protein and low-lipid cultivars for alternative uses, including search for hitherto unknown valuable compounds. Furthermore, strategies for use of complete thalli should be enforced, e.g., differential use of phylloids for abalone mariculture and the remaining thalli for alginic acid extraction. Some cultivars in our experiments developed hypertrophied holdfasts (800 to $1,000 \mathrm{~g}$ fresh weight per individual; Westermeier et al. 2011). This material is rich in protein and could be manufactured into abalone food pellets instead of presently being classified as a waste product.

Currently, laminarialean seaweeds are the most favorable food source for abalone: Production (or collection of natural material) costs are minimal and provide larger biomass than other macroalgae. Furthermore, it guarantees good stability in seawater and high palatability for marine herbivores. Moreover, immunostimulant, immunological, and dietetic fiber properties open perspectives for use as food in fishes, sea urchins, shrimps, goats, and cattle. In these cases, seaweeds could form an important base of diet regimes (Gojón-Baez et al. 1998; Agatsuma et al. 2002; Casas-Valdez et al. 2006; Dworjanyn et al. 2007; Cruz-Suarez et al. 2009; Dantagnan et al. 2009). Cultured high-performance genotype constructs of Macrocystis, like those outlined in our experiments, will provide an attractive basis for these new approaches in Chile.

Acknowledgments This work was partially founded by Volkswagen Foundation (Germany), International Foundation for Sciences (Sweden), Dirección de Investigación y Desarrollo UACh (Chile), and FONDEF de Conicyt (D00I1144 and D04I1288 grants, Chile). We thank F. Bascur and C. Atero for field assistance and support by Hagua and Hidrocultivos companies in mariculture installations. Finally, helpful suggestions from two anonymous reviewers are acknowledged also.

\section{References}

Agatsuma Y, Yamada Y, Taniguchi K (2002) Dietary effect of the boiled stipe of brown alga Undaria pinnatifida on the growth and gonadal enhancement of the sea urchin Strongylocentrotus nudus. Fish Sci 68:1274 1281 
AOAC (1990) Official methods of analysis. Association of Official Analytical Chemist, Washington, DC, 1298 pp

Black WAP (1948) Seasonal variation in chemical constitution of some of the sub littoral seaweeds common to Scotland. Part II. Laminaria digitata. J Soc Chem Ind 67:355 357

Cameron MC, Ross AG, Percival GV (1948) Methods for the routine estimation of mannitol, alginic acid and combined fucose in seaweeds. J Soc Chem Ind 67:161 164

Casas Valdez M, Hernández Contreras H, Marín Álvarez A, Águila Ramírez RN, Hernández Guerrero CJ, Sánchez Rodríguez I, Carrillo Domínguez S (2006) El alga marina Sargassum (Sargassaceae): una alternativa tropical para la alimentación de ganado caprino. Int J Trop Biol 54:83 92

Castro González MI, Carrillo Domínguez S, Pérez Gil F (1994) Chemical composition of Macrocystis pyrifera (Giant Sargazo) collected in summer and winter and its possible use in animal feeding. Cienc Mar 20:33 40

Chapman ARO, Craigie JS (1978) Seasonal growth in Laminaria longicruris: relations with reserve carbohydrate storage and production. Mar Biol 46:209 213

Coyer JA, Smith GJ, Anderson RA (2001) Evolution of Macrocystis spp. (Phaeophyceae) as determined by ITS1 and ITS2 sequences. J Phycol 37:574 585

Cruz Suarez LE, Tapia Salazar M, Nieto Lopez MG, Guajardo Barbosa C, Ricque Marie D (2009) Comparison of Ulva clathrata and the kelps Macrocystis pyrifera and Ascophyllum nodosum as ingredients in shrimp feeds. Aquac Nutrition 15:421 430

Dantagnan P, Hernández A, Bórquez A, Mansilla A (2009) Inclusion of macroalgae meal (Macrocystis pyrifera) as feed ingredient for rainbow trout (Oncorhynchus mykiss): effect on flesh fatty acid composition. Aquacult Res 41:87 94

Dubois M, Guilles KA, Hamilton JK, Rebers PA, Smith F (1956) Colorimetric method for determination of sugars and related substances. Anal Chem 28:350

Dworjanyn SA, Pirozzi I, Liu W (2007) The effect of the addition of algae feeding stimulants to artificial diets for the sea urchin Tripneustes gratilla. Aquaculture 273:624 633

Gerasimenko NI, Busarova NG, Moiseenko OP (2010) Age dependent changes in the content of lipids, fatty acids, and pigments in brown alga Costaria costata. Russ J Plant Physiol 57:62 68

Gojón Baez HH, Siqueiros Beltrones DA, Hernandez Contreras H (1998) In situ ruminal digestibility and degradability of Macro cystis pyrifera and Sargassum spp. in bovine livestock. Cienc Mar 24:463 481

Gómez I, Westermeier R (1995) Energy content and organic constituents in Antarctic and South Chilean marine brown algae. Polar Biol 15:597 602

Gorham J, Lewey SA (1984) Seasonal changes in the chemical composition of Sargassum muticum. Mar Biol 80:103 107

Graham MH, Vasquez JA, Buschmann AH (2007) Global ecology of the giant kelp Macrocystis: from ecotypes to ecosystems. Oceanogr Mar Biol Annu Rev 45:39 88

Hahn K (1989) Nutrition and growth of abalone. In: Hahn K (ed) Handbook of culture of abalone and other marine gastropods. CRC, Boca Raton, pp 135180

Hernández Carmona G, Carrillo Domínguez S, Arvizu Higuera DL, Rodríguez Montesinos YE, Murillo Álvarez Muñoz Ochoa M, Castillo Domínguez RM (2009) Monthly variation in the chemical composition of Eisenia arborea J.E. Areschoug. J Appl Phycol 21:607 616

Jensen A, Indergaard M, Holt TJ (1985) Seasonal variation in the chemical composition of Saccorhiza polyschides (Laminariales, Phaeophyceae). Bot Mar 28:375 381

Jones RF (1956) On the chemical composition of the brown alga Himanthalia elongata (L.) S.F. Gray. Biol Bull 110:169 178
Kraan S (2010) Mass cultivation of carbohydrate rich macroalgae, a possible solution for sustainable biofuel production. Mitig Adapt Strateg Glob Change. doi:10.1007/s11027 01092755

Lawrence JM, McClintock JB (1988) Allocation of organic material and energy to the holdfast, stipe, and fronds in Postelsia palmaeformis (Phaeophyta: Laminariales) on the California coast. Mar Biol 99:151 155

Macaya EC, Zucarello G (2010) DNA barcoding and genetic divergence in the giant kelp Macrocystis (Laminariales). J Phycol 46:736 742

Macchiavello J, Araya E, Bulboa C (2010) Production of Macrocystis pyrifera (Laminariales; Phaeophyceae) in northern Chile on spore based culture. J Appl Phycol 22:691 697

Mc Hugh D (2003) A guide to the seaweed industry. FAO Fisheries Technical Paper $N^{\circ}$ 441. Rome, Italy. Available at: www.FAO.org

McKee JWA, Kavalieris L, Brasch DJ, Brown MT, Melton LD (2002) Alginate content and composition of Macrocystis pyrifera from New Zealand. J Appl Phycol 4:357 369

Meeuse BJD (1962) Storage products. In: Lewin RA (ed) Physiology and biochemistry of algae. Academic, New York, pp 289291

Nelson MM, Phleger CF, Nichols PD (2002) Seasonal lipid composition in macroalgae of the northeastern Pacific ocean. Bot Mar 45:58 65

Paine RT, Vadas RL (1969) Calorific values of benthic marine algae and their postulated relation to invertebrate food preference. Mar Biol 4:79 86

Percival E (1979) The polysaccharides of green, red and brown seaweeds: their basic structure, biosynthesis and function. $\mathrm{Br}$ Phycol J 14:103 117

ProChile (2011) Estadísticas de comercio exterior. Available at: www. Prochile.cl

Reed RH, Davison IR, Chudek JA, Foster R (1985) The osmotic role of mannitol in the Phaeophyta: an appraisal. Phycologia 24:35 47

Robledo D, Freile Pelegrin Y (2005) Seasonal variation in photosyn thesis and biochemical composition of Caulerpa spp. (Bryop sidales, Chlorophyta) from the Gulf of Mexico. Phycologia 44:312 319

Rosell KG, Srivastava LM (1984) Seasonal variation in chemical constituents of the brown algae Macrocystis integrifolia and Nereocystis luetkeana. Can J Bot 62:2229 2236

Roughan PG (1985) Phosphatidylglycerol and chilling sensitivity in plants. Plant Physiol 77:740 746

Sernapesca (2009) Anuario Estadístico de Pesca. Ministerio de Economía Fomento y Reconstrucción, Chile. Available at: www.Sernapesca.cl

Smith KL, Harwood JL (1984) Lipids and lipid metabolism in the brown alga, Fucus serratus. Phytochemistry 23:2469 2473

Steubing L (1965) Pflanzenokologisches Praktikum. Parey, Hamburg, $262 \mathrm{p}$

Stockton B, Evans LV, Morris ER, Powell DA, Rees DA (1980) Alginate block structure in Laminaria digitata: implications for holdfast attachment. Bot Mar 23:563 567

van Tussenbroek BI (1989) Seasonal growth and composition of fronds of Macrocystis pyrifera in the Falkland Islands. Mar Biol 100:419 430

Westermeier R (1982) Zonierung, Biomasse, Energiehalt und Schwermetallakkumulation marinen algen aus Chile, Helgo land und Spanien. Ph.D. thesis, Justus Liebig Universitat, Giessen, $160 \mathrm{pp}$

Westermeier R (1987) Contenidos energéticos en una macroalga del sur de Chile, Durvillaea antartica (Cham.) Hariot (Phaeophyta, Fucales). In: Verreth A, Carrillo M, Zanuy S, Huisman EA (eds) Investigación Acuícola en América Latina. Pudoc, Wageningen, pp 367379 
Westermeier R, Gómez I (1996) Biomass, energy contents and major organic compounds in the brown alga Lessonia nigrescens (Laminariales, Phaeophyceae) from Mehuín, South Chile. Bot Mar 39:553 559

Westermeier R, Möller P (1990) Population dynamics of Macrocystis pyrifera (L.) C. Agardh in the rocky intertidal of southern Chile. Bot Mar 33:363 367

Westermeier R, Patiño DJ, Piel MI, Maier I, Müller DG (2006) A new approach to kelp mariculture in Chile: production of free floating sporophyte seedlings from gametophyte cultures of Lessonia trabeculata and Macrocystis pyrifera. Aquaculture Res 37:164 171

Westermeier R, Patiño DJ, Müller DG (2007) Sexual compatibility and hybrid formation between the giant kelp species Macrocystis pyrifera and M. integrifolia (Laminariales, Phaeophyceae) in Chile. J Appl Phycol 19:215 221

Westermeier R, Patiño D, Müller H, Müller DG (2010) Towards domestication of giant kelp (Macrocystis pyrifera) in Chile: selection of haploid parent genotypes, outbreeding, and heterosis. J Appl Phycol 22:357 361
Westermeier R, Patiño DJ, Murúa P, Müller DG (2011) Macrocystis mariculture in Chile: performance of heterosis genotype con structs under field conditions. J Appl Phycol 23:819 825

Wort DJ (1955) The seasonal variation in chemical composition of Macrocystis integrifolia and Nereocystis luetkeana in British Columbia coastal waters. Can J Bot 33:323 340

Zar JH (1999) Biostatistical analysis, 4th edn. Prentice Hall, Englewood Cliffs, $663 \mathrm{p}$

Zimmerman RC, Kremer JN (1986) In situ growth and chemical composition of the giant kelp, Macrocystis pyrifera: response to temporal changes in ambient nutrient availability. Mar Ecol Progr Ser 27:277 285

Zimmermann H, Zimmermann D, Reuss R, Feilen J, Manz B, Katsen A, Weber M, Ihmig FR, Ehrhart F, Gessner P, Behringer M, Steinbach A, Wegner LH, Sukhorukov VL, Vasquez JA, Schneider S, Weber MM, Volke F, Wolf R, Zimmermann U (2005) Towards a medically approved technology for alginate based microcapsules allowing long term immunoisolated transplantation. J Materials Sci: Mate rials in Medicine 16:491 501 